\title{
Predictors of Letter Knowledge in Children Growing in Poverty
}

\author{
Predictores del Conocimiento de las Letras en Niños que Crecen \\ en Contextos de Pobreza
}

\author{
Beatriz Diuk ${ }^{*}, a, b$ \& Marina Ferroni ${ }^{b}$ \\ ${ }^{a}$ Universidad Nacional de San Martín, San Martín, Argentina \\ $\&{ }^{b}$ Consejo Nacional de Investigaciones Científicas y Técnicas de Argentina, Buenos Aires, Argentina
}

\begin{abstract}
This study examined the influence of phonological processing abilities on letter knowledge and letter learning in $1^{\text {st }}$ grade children growing in poverty. At the beginning of the school year, 59 first graders were evaluated with tests measuring phonological awareness, phonological memory and rapid naming. Letter knowledge was assessed at the beginning and at the end of the year. All phonological processing abilities predicted letter knowledge at time 1, with phonological awareness producing the largest effect. However, only phonological memory predicted additional letter learning during the school year, once initial letter knowledge was taken into account.

Keywords: Letter Knowledge; Low-income Children; Phonological Processing Abilities.
\end{abstract}

\begin{abstract}
Resumen
El presente trabajo busca explorar la incidencia de las habilidades de procesamiento fonológico en el conocimiento y aprendizaje de letras en niños hispanohablantes de primer año de nivel socioeconómico (NSE) bajo. Al comenzar el año se evaluó el conocimiento de letras, la conciencia fonológica, la memoria fonológica y la denominación veloz. A fin de año se evaluó el conocimiento de letras. El análisis de la relación entre las medidas administradas se realizó en el grupo total y en un subgrupo con poco conocimiento alfabético. Los resultados sugieren que la conciencia fonológica tendría un papel fundamental en el inicio del aprendizaje, en tanto el aprendizaje adicional en el marco de la enseñanza escolar estaría asociado a las diferencias individuales en memoria fonológica.

Palabras clave: Conocimiento de Letras; Niños de NSE Bajo; Habilidades de Procesamiento Fonológico.
\end{abstract}

Letter knowledge is one of the best predictors of reading and spelling acquisition (Bravo-Valdivieso, Villalón, \& Orellana, 2006; Lerväg, Bratën, \& Hulme, 2009; Muter, Hulme, Snowling, \& Stevenson, 2004). Some authors contend that, in the early years of schooling, letter knowledge is an even better predictor of literacy acquisition than phonological awareness (Muter, Hulme, Snowling, \& Taylor, 1998; Scarborough, 1998). Additionally, there is evidence that children who experience reading difficulties have less alphabetic knowledge than children without difficulties (Gang \& Siegel, 2002; Pennington \& Lefly, 2001; Snowling, Gallagher, \& Frith, 2003).

The importance of letter knowledge might be related to the fact that letters help establish associations between oral words and their orthographic forms (Alves Martins \& Silva, 2001; Bowman \& Treiman, 2002; CardosoMartins \& Batista, 2005; Corrêa, Cardoso-Martins, \& Rodrigues, 2010; Pollo, Treiman, \& Kessler, 2008). Given the relevance of letter knowledge for reading and spelling

\footnotetext{
* Address: Consejo Nacional de Investigaciones Científicas y Técnicas, Av. Rivadavia, 1917, Buenos Aires, Argentina, C1033AAJ. E-mails: beadiuk@gmail.com and marinaferroni8@hotmail.com
}

acquisition, it seems surprising that it has gone relatively unattended in reading psychology and little is known about the cognitive abilities related to its development. According to de Jong and Olson (2004), the limited interest in letter acquisition derives from the fact that individual differences in this knowledge have been attributed to experiential factors such as school and home environments (Burgess, Hecht, \& Lonigan, 2002; Levy, Gong, Hessels, Evans, \& Jared, 2006).

However, these factors cannot account for all the variation found among children. It seems likely that environmental variables interact with individual differences in cognitive abilities related to letter acquisition. Given that letter recognition demands processing mechanisms similar to those involved in reading (Neuhaus, 2002), it is possible that the phonological processing abilities associated with reading - phonological awareness, phonological memory and rapid naming, may also predict letter knowledge (Lonigan et al., 2009). Phonological awareness refers to the ability to recognize and manipulate the sound structure of oral language. This skill may help children infer letter-sound correspondences, since the ability to identify the initial sound in words might promote the establishment of an association between the 
oral word's initial sound and the written word's initial letter (Lonigan, Burgess, \& Anthony, 2000).

Phonological memory refers to the temporary storage of information in a sound-based system of representation. Given the relation between phonological memory and new word learning in paired-associate tasks (Gathercole \& Baddeley, 1993) and the fact that letter names can be considered unknown words, it seems reasonable to predict that there might be an association between phonological memory and letter learning.

It is much less clear which abilities underlie performance in rapid naming tasks. Some researchers consider that these tasks tap the ease of recovering phonological codes from long-term memory (Torgesen, Wagner, Rashote, Burgess, \& Hetch, 1997), while others regard rapid naming as an independent source of variation not related to phonological processing (Wolf \& Bowers, 1999). It has been suggested that this task reflects the ability to learn arbitrary associations (Manis, Seidenberg, \& Doi, 1999). Since the relation between letter names and their graphic forms is arbitrary, rapid naming might predict letter knowledge.

Some studies have provided empirical evidence for an association between phonological processing and alphabetic knowledge. One of the abilities that has been systematically identified as a predictor of letter knowledge is phonological awareness. Carroll, Snowling, Hulme and Stevenson (2003) reported high correlation coefficients between letter knowledge and a latent variable composed of sensitivity to rimes and syllables. Lindsey, Manis and Bailey (2003) found statistically significant correlations between measures of phonological awareness and letter knowledge in the three waves of their longitudinal study from kindergarten to end of $1^{\text {st }}$ grade. Capovilla and Capovilla (2000) have shown that training in phonological awareness and letter-sound associations improved letter knowledge in low-income 1st grade children. Lonigan et al. (2000) found a bidirectional relationship between phonological sensitivity and letter knowledge, a relationship that has also been reported by other authors (Foy \& Mann, 2006).

Torppa, Poikkeus, Laakso, Eklund and Lyytinen (2006) found that the best predictors of individual differences in letter acquisition were phonological processing abilities. De Jong and Olson (2004) evaluated which abilities predicted letter learning in preschool Dutch children. They tested children's phonological memory, vocabulary and rapid naming of objects. They found an effect of phonological memory that was particularly related to the ability to repeat nonwords. Rapid naming had a small effect but vocabulary had no effect on letter learning. In a study involving 5-year-old Canadian children, Evans, Bell, Shaw, Moretti and Page (2006) found that a measure of cognitive ability, which included receptive vocabulary, non verbal reasoning, rapid naming of objects and phonological memory had significant correlations with alphabetic knowledge.
Now, the research reviewed up to this point has mainly included children from middle-income families. In the present study, letter knowledge predictors are analyzed in children growing in poverty. For some of these children letter learning seems to represent a considerable challenge. Molfese et al. (2006) evaluated knowledge of letters in low-income 4-year-old children and found that, at the beginning of the school year, they recognized an average of 6 letters. But $53 \%$ of the children with lower initial knowledge failed to learn more than one additional letter along the whole year. Diuk and Moras (2009) compared low-income 8-to-12 year old children who experienced difficulties in reading acquisition to reading level younger controls from the same socioeconomic background. Statistically significant differences were only found in letter knowledge.

Consequently, the aim of this study is to evaluate letter knowledge in low-income children entering 1st grade, together with cognitive abilities which might be concurrent predictors of alphabetic knowledge: phonological awareness, phonological memory and rapid naming. Additionally, given the evidence showing that low-income children tend to enter school with low alphabetic knowledge, it seems likely that they will continue developing this knowledge throughout the school year. Consequently, letter knowledge was tested again at the end of the year so as to determine the influence of cognitive abilities tested at the beginning of the year on the letter learning that takes place during the $1^{\text {st }}$ year of schooling.

\section{Method}

\section{Participants}

Participants were 59 children (30 boys and 29 girls) who entered 1st grade in a parochial school that served low-socioeconomic status families from Buenos Aires. Three other children from the same groups were excluded: one of them had serious behavioral problems, one girl suffered a prolonged illness which coincided with the initial evaluations and a third boy presented a high degree of malnutrition which affected his performance.

Socioeconomic status was established based on the selfreported occupation of the child's adult guardian: $8 \%$ of the adults were unemployed while the rest held jobs corresponding to the lower levels (1 and 2) of a 7-pont occupational status scale by Sautú (1992). The assessment of the children was part of a project that included a teacher development strategy coordinated by the first author of this paper. The school informed parents of the project and requested children's participation. Parents signed informed consents.

\section{Measures}

Phonological Sensitivity Tests. (a) Syllable-matching task: the task was adapted from Signorini and Borzone de Manrique (1996). A stimulus picture was displayed and named. The children were asked to identify which of 
two words (also illustrated) began with the same sound as the stimulus. If the child pointed to one of the drawings, he or she was asked to name the word. Feedback was only provided during practice trials. The task consisted of three practice trials and ten test trials. One point was given for each correct answer. Internal consistency reliability was calculated using Cronbach's alpha: .72. (b) Initial sound matching task: the task has the same structure as the syllable-matching task but target words only share the initial phoneme. Cronbach's alpha for this sample was .58. (c) Letter knowledge: children were presented with 25 upper case letters and asked to name them. Each letter appeared individually in the center of a white page, Arial font, size 150. Either the letter's name or sound were considered correct answers. One point was given for each correct answer. Cronbach's alpha was .93 when the children entered school and .96 at the end of the year. (d) Rapid naming: two rapid-naming tasks were administered, designed after Denckla and Rudel's (1976) RAN test: a vowel naming task (A, E, I, O, U) and a digit naming task (1 to 5). In both cases, each item was presented 10 times. (e) Pseudoword repetition: based on syllable frequency established by Alameda and Cuetos (1995), a list of 40 pseudowords was developed. Pseudowords varied in length and syllable frequency. The list was presented to 15 adults who were native speakers of Spanish and who were asked to grade pseudoword's similarity to Spanish real words in a 4-point scale. Based on this evaluation, 12 pseudowords were selected, which had been considered not similar to Spanish words by $80 \%$ of the subjects. These pseudowords were orally presented for repetition to the children by the first author of this paper. Children's performance was both manually registered and recorded in audio. The second author of this paper graded the children's repetitions based on the audio tape. In case of disagreement, recordings were re-analyzed until consensus was obtained. Cronbach's alpha for this test was .62.

\section{Procedure}

Initial evaluation took place in a quiet room in the children's school in the second month of classes.

Each child participated in two sessions in which tests were administered in fixed order. The two phonological sensitivity tasks were presented in different sessions. Towards the end of the year, letter knowledge was reassessed. Administration of all tasks was conducted by the first author of this paper together with two school logo therapists and the school's speech therapist, who had been trained for administration of the tests.

\section{Results}

Due to lack of knowledge of the vowels, 32\% of the children could not complete the rapid naming of vowels task. Consequently, the test was excluded from the analyses and rapid naming skills were only assessed with the digit naming task. Table 1 presents the descriptive statistics for each of the tests administered at the beginning of the year.

Table 1

Descriptive Statistics for the whole Sample at the Beginning of the Year

\begin{tabular}{lrcr}
\hline Task & Mean & Standard deviation & Range \\
\hline Syllable recognition (Max.= 10) & 8.14 & 1.79 & $4-10$ \\
Initial sound recognition (Max= 10) & 7.56 & 1.87 & $4-10$ \\
Letter knowledge (Max= 25) & 16.63 & 6.27 & $3-25$ \\
RAN digits letters/secs) & .74 & .29 & $0-1.47$ \\
Nonword repetition (Max= 12) & 5.53 & 2.35 & $0-10$ \\
\hline
\end{tabular}

In order to obtain a unified measure of phonological awareness, an exploratory factor analysis of main components was conducted on the tests of initial sound and syllable matching. The measure obtained is the one used in the following analyses.

The relation between letter knowledge and the rest of the measures assessed at the beginning of the year was examined by means of the correlations analysis presented in Table 2. All correlations between predictor measures and letter knowledge were positive and statistically significant. These results provide empirical evidence to the association between phonological processing abilities and initial alphabetic knowledge.
Table 2

Correlations among Tasks at the Beginning of the School Year

\begin{tabular}{lrrr}
\hline & 1 & 2 & 3 \\
\hline 1. Letter knowledge & - & & \\
2. Phonological sensitivity & $.627^{* * *}$ & - & \\
3. RAN digits & $.618^{* * *}$ & $.452^{* * *}$ & - \\
4. Nonword repetition & $.451^{* * *}$ & $.261^{*}$ & $.408^{* * *}$ \\
\hline$* p<.05 \cdot * * p<.01 ; * * * p<.001$ & &
\end{tabular}


To further investigate the association found, a series of regression analyses were performed in order to examine the specific contribution of the different predictor measures on letter knowledge. Phonological awareness, phonological memory and rapid naming of digits were introduced as predictor variables. Results are shown in Table 3.

Table 3

Percentages of Variance in Letter Knowledge at the Beginning of the Year Accounted for by Predictor Measures

Predictor

\begin{tabular}{ll}
\hline Nonword repetition & $4.1^{*}$ \\
RAN digits & $11.9^{* *}$ \\
Phonological sensitivity & $17.5^{* * *}$ \\
Total $R^{2}$ & 54.4
\end{tabular}

${ }^{*} p<.05 ; * * p<.01 ; * * * p<.001$.
Taken together, the variables included in the analyses accounted for $54.4 \%$ of the variance in letter knowledge. All the predictor measures made independent contributions to letter knowledge, with phonological sensitivity as the main predictor, followed by rapid naming of digits and with phonological memory making a smaller contribution.

The second aim of this study was to identify predictor variables of additional letter learning during the first grade. Children who had performed at ceiling level at the beginning of the year were excluded from this analysis, leaving a sample of 40 children who had recognized less than 21 letters. Table 4 shows descriptive statistics for this subgroup.

Average letter recognition in this subgroup was 13.38 at the beginning of the year and 20.80 at the end. A repeated measures ANOVA revealed statistically significant differences between these scores $(F(1,39)=$ 159.925, $p=.000)$, indicating that letter learning had occurred along the year.

Table 4

Descriptive Statistics for the Low-skill Group at Beginning and End of Year

\begin{tabular}{lrcr}
\hline Task & Mean & Standard deviation & Range \\
\hline Syllable recognition (Max.= 10) & 7.65 & 1.86 & $4-10$ \\
Initial sound recognition (Max= 10) & 6.95 & 1.79 & $4-10$ \\
Letter knowledge T1 (Max= 25) & 13.38 & 4.91 & $3-21$ \\
Letter knowledge T2 (Max= 25) & 20.80 & 3.37 & $11-25$ \\
RAN digits (letters/secs) & .65 & .24 & $0-1.16$ \\
Nonword repetition (Max= 12) & 4.00 & 2.04 & $0-9$ \\
\hline
\end{tabular}

It has been suggested that variation in unselected samples and variation in a low-performing subgroup may have different predictors (Pennington \& Lefly, 2001). Consequently, in the first place, correlations between letter knowledge at the beginning of the year and the predictor variables assessed were recalculated. Positive and significant correlations were found between letter recognition and rapid naming of digits $(r=.558, p=.000)$ and phonological sensitivity $(r=.472, p=.002)$ but not between letter knowledge and pseudoword repetition $(r=.296, p$ $=.063$ ). The pattern of associations among variables was thus somewhat different from the one obtained for the whole sample, where a correlation between letter recognition and phonological memory had been found.

Correlations were then calculated between predictor variables measured at the beginning of the year and letter knowledge at the end of the year. Positive significant correlations were found between letter knowledge at the two testing times $(r=.655, p=.000)$ and between letter knowledge at the end of the year and rapid naming of digits $(r=.516, p=.001)$ and pseudoword repetition $(r=$ $.486, p=.001$ ) but not with phonological awareness $(r=$ $.214, p=.184)$.
All time 1 predictor variables were introduced in two stepwise regression analyses with letter knowledge at the beginning and at the end of the year as the dependent variable in each one. As can be seen in Table 5, in this subgroup of children, as opposed to the whole sample, nonword repetition did not have an independent effect on letter knowledge in time 1 . In time 2, however, both nonword repetition and rapid naming contributed to letter knowledge at the end of the year.

\section{Table 5}

Percentages of Variance in Low-performing Group's Letter Knowledge at the Beginning and at the End of the Year Accounted for by Initial Predictor Measures

\begin{tabular}{lcc}
\hline \multirow{2}{*}{ Predictor } & \multicolumn{2}{c}{ Dependent variables } \\
\cline { 2 - 3 } & $\begin{array}{l}\text { Letter knowledge } \\
\text { Beginning of year }\end{array}$ & $\begin{array}{c}\text { Letter knowledge } \\
\text { End of year }\end{array}$ \\
\hline Nonword repetition & 2.30 & $13.90^{*}$ \\
RAN digits & $16.30^{* *}$ & $14.50^{*}$ \\
Phonological sensitivity & $12.10^{*}$ & 0.84 \\
Total $R^{2}$ & 39.40 & 34.80 \\
\hline
\end{tabular}

$* p<.05 ; * * p<.01 ; * * * p<.001$. 
Previous analyses did not include letter knowledge at the beginning of the year as an autoregressor. When this independent variable was included, it showed a significant effect on letter knowledge at the end of the year (see Table 6). Only phonological memory still contributed to letter knowledge once the autoregressor was included.

Table 6

Percentages of Variance in Letter Knowledge at the End of the Year Accounted for by Phonological Processing Predictor Measures and by Initial Letter Knowledge

\begin{tabular}{lc}
\hline \multicolumn{1}{c}{ Predictor } \\
\hline Letter knowledge beginning of year & $26.5^{* *}$ \\
Nonword repetition & $8.12^{*}$ \\
RAN digits & 2.90 \\
Phonological sensitivity & 0.75 \\
$R^{2}$ total & 49.20 \\
\hline${ }^{*} p<.05 ;{ }^{* *} p<.01$. &
\end{tabular}

\section{Discussion}

This paper aimed at exploring which cognitive/linguistic skills predicted letter knowledge in a group of low-income $1^{\text {st }}$ grade children. In the first place, concurrent predictors of initial letter knowledge were analyzed. In coincidence with previous studies, (de Jong \& Olson, 2004; Evans et al., 2006; Torppa et al., 2006), it was found that phonological sensitivity, verbal memory and rapid naming had an effect on this knowledge.

Given the difficulties that many low-income children experience in acquiring alphabetic knowledge, a particular interest was taken in those children who exhibited low performance at school entry. A subset of 40 children with initial low letter knowledge was selected and concurrent and longitudinal predictors of this knowledge were analyzed.

At the beginning of the year, phonological sensitivity and rapid naming showed an effect on concurrent letter knowledge. The relation between phonological sensitivity and alphabetic knowledge has been amply documented (Burgess \& Lonigan, 1998; Capovilla \& Capovilla, 2000; Lindsey et al., 2003; Lonigan et al., 2009; Lonigan, et al., 2000; Signorini \& Borzone de Manrique, 1996; Torppa et al., 2006). Lonigan et al. (2000) suggest that phonological awareness' contribution to letter learning arises from the fact that children's ability to identify phonemic boundaries in oral words might ease the establishment of an association between the word's first sound and the first letters they see in print. Thus, children with higher sensitivity to the sound structure of words may benefit more from early informal exposure to print.

On the other hand, in coincidence with results obtained by de Jong and Olson (2004) with Dutch children and by Anthony et al. (2006) with Spanish-speaking children, rapid naming of digits made an independent contribution to letter knowledge both at the beginning and at the end of the year, although this effect disappeared once letter knowledge at the beginning of the year was included in the regression on end-of-year performance.

As pointed in the introduction, there is no consensus among researchers as to which processes underlie the rapid naming task. In the present study, RAN's effect on initial letter knowledge remained significant even when entered after phonological memory and phonological sensitivity, suggesting that rapid naming's contribution went beyond the task's phonological component. The idea has been advanced that the rapid naming task taps the child's ability to rapidly integrate the different processes implicated in identifying and naming a digit or letter and that it is this integration feature which underpins the association between rapid naming and letter knowledge, given that letter learning requires the integration of verbal, visual and attentional systems (Neuhaus \& Swank, 2002).

Other authors, however, have pointed that letter learning does not share the temporal demand of RAN tasks (de Jong \& Olson, 2004) and suggest, following Manis et al. (1999) that the rapid naming task reflects the ability to establish arbitrary associations. Similarly, CardosoMartins and Pennington (2004) consider alphanumeric RAN tasks as indicators of the ability to form associations between letters in writing and sounds in pronunciation.

One of the most interesting results in this study refers to the fact that in the low-performing group, different skills predicted letter knowledge at the beginning and at the end of the year. Phonological memory had a minor role as a concurrent predictor in initial knowledge but it was the only task that made an independent contribution to end of year letter knowledge even when previous letter knowledge was included in the regression.

Different studies have found phonological memory and letter knowledge to be related (de Jong \& Olson, 2004; Evans et al., 2006; Torppa et al., 2006). De Jong and Olson (2004) interpret the role of phonological memory within a two-step process of letter learning. In the first step, a temporary phonological representation of the letter's name or sound is set up in phonological memory. In the second step, this temporary phonological representation is established in long - term memory linked to the letter's graphic form.

Consequently, it seems likely that the different roles of phonological sensitivity and phonological memory at the beginning and at the end of the year are reflecting the different learning environments in which children participated. Indeed, before school entry the children had not been taught letter names or sounds systematically as they were once they entered $1^{\text {st }}$ grade. The relation between initial letter knowledge and phonological sensitivity might be reflecting the fact that the children with more developed phonological sensitivity were better able to infer lettername or letter-sound associations from the informal activities that took place in kindergarten. 
On the other hand, during the $1^{\text {st }}$ school year, letters were systematically taught in the classrooms: initial sounds of words were identified, corresponding letters were introduced and their names and sounds were drilled. It seems reasonable to assume that within these situations, individual differences in letter learning were related to phonological memory.

Taken together, the results from this study suggest that the abilities that predict letter knowledge in low-income children are the same as those reported in research including children from other socioeconomic backgrounds, even if a somewhat different pattern of associations was found at different testing times. Phonological sensitivity has a fundamental role at the beginning of the letter-learning process while additional learning in the context of systematic teaching at school is related to individual differences in phonological memory.

\section{References}

Alameda, J. R., \& Cuetos, F. (1995). Diccionario de frecuencias de las unidades lingüísticas del castellano: Vols. I - II. Oviedo, España: Servicio de publicaciones de la Universidad de Oviedo.

Alves Martins, M., \& Silva, C. (2001). Letter names, phonological awareness and the phonetization of writing. European Journal of Psychology of Education, 16(4), 605-617.

Anthony, J. L., Williams, J. M., McDonald, R., Corbitt-Shindler, D., Carlson, C. D., \& Francis, D. J. (2006). Phonological processing and emergent literacy in Spanish-speaking preschool children. Annals of Dyslexia, 56(2), 239-270.

Bowman, M., \& Treiman, R. (2002). Relating print and speech: The effects of letter names and word position on reading and spelling performance. Journal of Experimental Child Psychology, 82, 305-340.

Bravo-Valdivieso, L., Villalón, M., \& Orellana, E. (2006). Predictibilidad del rendimiento en lectura: una investigación de seguimiento entre primer y tercer año. Revista Latinoamericana de Psicología, 38, 9-20.

Burgess, S. R., Hecht, S. A., \& Lonigan, C. J. (2002). Relations of the Home Literacy Environment (HLE) to the development of reading-related abilities: A one-year longitudinal study. Reading Research Quarterly, 37, 408-426.

Burgess, S. R., \& Lonigan, C. J. (1998). Bidirectional relations of phonological sensitivity and prereading abilities. Journal of Experimental Child Psychology, 70, 117-141.

Capovilla, A., \& Capovilla, F. (2000). Efeitos do treino de consciência fonológica em crianças com baixo nível sócio-econômico. Psicologia: Reflexão e Crítica, 13(1), 7-24.

Cardoso-Martins, C., \& Batista, A. C. E. (2005). O conhecimento do nome das letras e o desenvolvimento da escrita: Evidência de crianças falantes do português. Psicologia: Reflexão e Crítica, 18(3), 330-336.

Cardoso-Martins, C., \& Pennington, B. (2004). The relationship between phoneme awareness and rapid serial naming skill and literacy acquisition: The role of developmental period and reading ability. Scientific Studies of Reading, 8(1), 2752.

Carroll, J. M., Snowling, M. J., Hulme, C., \& Stevenson, J. (2003). The development of phonological awareness in preschool children. Developmental Psychology, 39, 913-923.
Corrêa, M., Cardoso-Martins, C., \& Rodrigues, L. (2010). O conhecimento do nome das letras e a sua relação com o desenvolvimento da escrita: Evidência de adultos iletrados. Psicologia: Reflexão e Crítica, 23, 330-336.

de Jong, P. F., \& Olson, R. K. (2004). Early predictors of letter knowledge. Journal of Experimental Child Psychology, 8, 254-273.

Denckla, M. B., \& Rudel, R. (1976). Rapid automatized naming (RAN): Dyslexia differentiated from other learning disabilities. Neuropsychologia, 14, 471-479.

Diuk, B., \& Moras, C. (2009). Las dificultades de aprendizaje de la lectura y la escritura en niños que crecen en contextos de pobreza. Perspectivas en Psicología, 6(1), 22-29.

Evans, M. A., Bell, M., Shaw, D., Moretti, S., \& Page, J. (2006). Letter names, letter sounds and phonological awareness: An examination of kindergarten children across letters and of letters across children. Reading and Writing, 19, 959-989.

Foy, G., \& Mann, V. (2006). Changes in letter sound knowledge are associated with development of phonological awareness in pre-school children. Journal of Research in Reading, 29(2), 143-161.

Gang, M., \& Siegel, L. (2002). Sound-symbol learning in children with dyslexia. Journal of Learning Disabilities, 35(2), 137-157.

Gathercole, S. E., \& Baddeley, A. D. (1993). Working memory and language. Cambridge, UK: Psychology Press.

Lerväg, A., Bräten, I., \& Hulme, C. (2009). The cognitive and linguistic foundations of early reading development. Developmental Psychology, 45, 764-781.

Levy, B. A., Gong, Z., Hessels, S., Evans, M. A., \& Jared, D. (2006). Understanding print: Early reading developments and the contributions of home literacy experiences. Journal of Experimental Child Psychology, 93, 63-93.

Lindsey, K. A., Manis, F. R., \& Bailey, C. E. (2003). Prediction of first-grade reading in Spanish- speaking English-language learners. Journal of Educational Psychology, 95, 482-494.

Lonigan, C. J., Anthony, J. L., Philips, B. M., Purpura, D. J., Wilson, S. B., \& McQueen, J. D. (2009). The nature of preschool phonological processing abilities and their relations to vocabulary, general cognitive abilities, and print knowledge. Journal of Educational Psychology, 2, 345-358.

Lonigan, C. J., Burgess, S. R., \& Anthony, J. L. (2000). Development of emergent literacy and early reading skills in preschool children: Evidence of a latent variable longitudinal study. Development Psychology, 36, 596-613.

Manis, F. R., Seidenberg, M. S., \& Doi, L. M. (1999). See Dick RAN: Rapid naming and the longitudinal prediction of reading sub skills in first and second grades. Scientific Studies of Reading, 3, 129-157.

Molfese, V. J., Modglin, A. A., Beswick, J. L., Neamon, J. D., Berg, S. A., Berg, C. J., et al. (2006). Letter knowledge, phonological processing, and print knowledge: Skill development in nonreading preschool children. Journal of Learning Disabilities, 39(4), 296-305.

Muter, V., Hulme, C., Snowling, M., \& Stevenson, J. (2004). Phonemes, rhymes, vocabulary and grammatical skills as foundation of early reading development: Evidence from a longitudinal study. Development Psychology, 40, 665-681.

Muter, V., Hulme, C., Snowling, M., \& Taylor, S. (1998). Segmentation, not rhyming, predicts early progress in learning to read. Journal of Experimental Child Psychology, 71, 3-27.

Neuhaus, G. (2002). What does it take to read a letter? Perspectives, 28, 6-8. 
Neuhaus, G. F., \& Swank, P. R. (2002). Understanding the relation between RAN letters subtest components and word reading in first grade student. Journal of Learning Disabilities, 35(2), 158-174.

Pennington, B. F., \& Lefly, D. L. (2001). Early reading development in children with familiar risk for dyslexia. Child Development, 72(3), 816-833.

Pollo, T., Treiman, R., \& Kessler, B. (2008). Preschoolers use partial letter names to select spellings: Evidence from Portuguese. Applied Psycholinguistics, 29, 195-212.

Sautú, R. (1992). Teoría y medición del estatus ocupacional. Escalas ocupacionales objetivas y de prestigio. Cuadernos del Instituto de Investigaciones (Buenos Aires), 10.

Scarborough, H. S. (1998). Early identification of children at risk for reading disabilities: Phonological awareness and some other promising predictors. In B. K. Shapiro, P. J. Accardo, \& A. J. Capute (Eds.), Specific reading disability: A view of the spectrum (pp. 75-119). Timonium, MD: York Press.

Signorini, A., \& Borzone de Manrique, A. M. (1996). Las habilidades metafonológicas, la lectura y la escritura en niños de cinco años. Lenguas Modernas, 23, 71-93.

Snowling, M. J., Gallagher, A., \& Frith, U. (2003). Family risk of dyslexia is continuous: Individual differences in the precursors of reading skill. Child Development, 74, 358-373.

Torgesen, J. K., Wagner, R. K., Rashote, C. A., Burgess, S., \& Hetch, S. (1997). Contribution of phonological awareness and rapid automatic naming ability to the growth of wordreading skills in second to fifth grade children. Scientific Studies of Reading, 1, 161-185.

Torppa, M., Poikkeus, A. M., Laakso, M. L., Eklund, K., \& Lyytinen, H. (2006). Predicting delayed letter knowledge development and its relation to Grade 1 reading achievement among children with and without familial risk for dyslexia. Developmental Psychology, 42, 1128-1142.

Wolf, M., \& Bowers, P. (1999). The double-deficit hypothesis for the developmental dyslexias. Journal of Educational Psychology, 3, 415-438. 